\title{
Hibiscus acid from Hibiscus sabdariffa (Malvaceae) has a vasorelaxant effect on the rat aorta
}

\author{
Ahmed M. Zheoat ${ }^{\mathrm{a}}$, Alexander I. Gray ${ }^{\mathrm{a}}$, John O. Igoli ${ }^{\mathrm{b}}$, Valerie A. Ferro ${ }^{\mathrm{a}}$, and Robert M. \\ Drummond ${ }^{\mathrm{a}}$. \\ ${ }^{\text {a }}$ Strathclyde Institute of Pharmacy and Biomedical Sciences, University of Strathclyde, 161 \\ Cathedral Street, Glasgow G4 0RE, Scotland. \\ ${ }^{\mathrm{b}}$ Phytochemistry Research Group, Department of Chemistry, University of Agriculture PMB \\ 2373 Makurdi, Nigeria.
}

Corresponding author: Robert M. Drummond (robert.drummond@strath.ac.uk)

Strathclyde Institute of Pharmacy and Biomedical Sciences, University of Strathclyde, 161 Cathedral Street, Glasgow G4 0RE, Scotland. 


\begin{abstract}
Hibiscus sabdariffa (Malvaceae) is a plant that is widely recognised for its antihypertensive properties; however the constituent(s) responsible for this biological activity are presently unknown. The aim of this study was to identify the potential compounds that are responsible for the vasorelaxant activity of $H$. sabdariffa. Thereafter, the mechanisms involved in producing the vasorelaxation were investigated. The plant was extracted consecutively with hexane, ethyl acetate and methanol. The methanolic extract was subjected to bioassay-guided fractionation in order to isolate pure compounds that possessed vasorelaxant activity. The vascular effects of the pure compounds were studied on the rat aorta in vitro using myography techniques. Hibiscus acid produced a concentration-dependent relaxation of the rat aorta precontracted with either phenylephrine $(3 \mu \mathrm{M})$ or $\mathrm{KCl}(60 \mathrm{mM})$, irrespective of the presence of the endothelium. When the tissue was pre-contracted with phenylephrine, the concentration required to produce $50 \%$ relaxation $\left(\mathrm{IC}_{50}\right)$, was $0.09 \pm 0.01 \mathrm{mg} / \mathrm{ml}$. Hibiscus acid had no effect on the phasic contraction induced by phenylephrine in $\mathrm{Ca}^{2+}$-free physiological solution; but it did affect the component of the contraction that is due to $\mathrm{Ca}^{2+}$ influx. In parallel studies, garcinia acid, a diastereoisomer of hibiscus acid, was found to have an almost identical vasorelaxant effect. The vasorelaxant action of both compounds is most likely due to the inhibition of $\mathrm{Ca}^{2+}$ influx via voltage-dependent $\mathrm{Ca}^{2+}$ channels.
\end{abstract}

Keywords: Hibiscus sabdariffa; Hibiscus acid; Garcinia acid; Vascular smooth muscle; Vasorelaxation; $\mathrm{Ca}^{2+}$ channels. 


\section{Introduction}

The red calyces of Hibiscus sabdariffa (H. sabdariffa) (from the family Malvaceae), commonly known as Karkade or Red sorrel, have been used in many countries throughout the world for their health benefits, particularly as a treatment for hypertension [1-3]. The antihypertensive activity of $H$. sabdariffa has also been studied clinically on patients with high blood pressure. These studies have shown that regular daily consumption of hibiscus tea caused a clinically significant reduction of approximately $10 \%$ in both systolic and diastolic blood pressure [4-9]. The magnitude of the effect of hibiscus tea was similar to that obtained with the angiotensin converting enzyme inhibitors captopril or lisinopril $[5,6]$.

A number of in vivo studies have also shown the blood pressure reducing activity of $H$. sabdariffa calyces in hypertensive animals [10-13]. For example, in salt-induced hypertensive rats, the aqueous extract of the calyxes lowered both systolic and diastolic blood pressure by 6 and $7 \mathrm{mmHg}$, respectively [13]. There have also been a number of in vitro studies examining the vasorelaxant effects of the crude extracts of $H$. sabdariffa. Both aqueous and alcohol extracts of hibiscus calyces produced vasorelaxation of the aorta pre-contracted with either an adrenoceptor agonist or by depolarization [14-18]. The vasorelaxation was proposed to occur through both direct and indirect mechanisms; specifically, by blocking $\mathrm{Ca}^{2+}$ entry in smooth muscles cells and by stimulation of endothelial-derived relaxing factor respectively $[17,18]$. These crude extracts have also been shown to have inhibitory effects on the contractility of other smooth muscle tissues including the intestine, uterus, and bladder [19, 20].

Phytochemical studies on the calyces have shown that they contain a number of organic acids (hydroxycitric and hibiscus), flavonoids (quercetin, hibiscetin, and gossypetin), and 
anthocyanins (hibiscin) [3]. However, the compounds which are responsible for the antihypertensive activity of $H$. sabdariffa are still unclear. Therefore, the initial aim of this study was to determine which constituent(s) is (are) responsible for this vasorelaxant activity. Thereafter, the activity of the pure compound was compared to the vasorelaxant activity of the crude methanolic extract of this plant. Subsequent studies were carried out to determine the mechanism of action for the vasorelaxant activity of the pure compound on the rat aorta.

\section{Materials and Methods}

\subsection{Plant materials}

H. sabdariffa (Malvaceae) was provided by Professor John Igoli. It was collected from Makurdi in Benue State Nigeria and identified at the Herbarium of the National Institute for Pharmaceutical Research and Development (Abuja, Nigeria) by Dr. Jemilat Ibrahim where a voucher specimen number NIPRD/H/6972 was deposited.

\subsection{Extraction and purification procedures}

We have carried out extraction of the dry calyces in a sequential manner with n-hexane, ethyl acetate and methanol (72 h each) using a Soxhlet apparatus. The extract was then fractionated using chromatographic techniques, and compound identification was carried out using NMR spectroscopy, Mass spectroscopy, and X-ray crystallography [21]. The methanolic crude extract of $H$. sabdariffa calyces was then dissolved in a small volume of methanol and loaded to the top of a Sephadex ${ }^{\circledR}$ LH20 column (GE Healthcare, UK). The column was then eluted with methanol, yielding 5 subfractions (HS-F1 (6\%), HS-F2 (25\%), HS-F3 (29\%), HS-F4 (12\%), and HS-F5 (6\%)). A preliminary bioactivity-led fractionation process was carried out to examine the vasorelaxant activity of these subfractions using myography techniques (See section 2.4 below), where subfractions (HS-F2, HS-F3, HS-F4, and HS-F5) were found to cause vasorelaxation of the aorta. NMR analysis showed that subfractions HS-F2, HS-F3, and 
HS-F4 are enriched with hibiscus acid and its derivatives, hibiscus acid methyl ester and hibiscus acid dimethyl ester, while HS-F5 was almost pure hibiscus acid. This result led us to isolate and further purify hibiscus acid, which was prepared in a purity of $\geq 95 \%$ (Figure $1 \mathrm{~A}$ ) from the calyces as described previously [21]. Hibiscus acid is not commercially available; however, it is a chiral compound and its diastereomer, garcinia acid (GA) from (Garcinia cambogia) is commercially available, (Figure 1B). Therefore, we have carried out parallel studies with garcinia acid, in order to determine if it had a similar vasorelaxant effect to hibiscus acid.<smiles>O=C1C[C@](O)(C(=O)O)[C@H](C(=O)O)O1</smiles>

A<smiles>O=C1C[C@](O)(C(=O)O)[C@H](C(=O)O)O1</smiles>

B

Figure 1: Structures of hibiscus acid (A) and garcinia acid (B).

\subsection{Drugs, solvents and chemicals}

(+)-Garcinia acid, R-(-)-phenylephrine hydrochloride, 1, 4-dihydro-2,6-dimethyl-5-nitro-4(2-[trifluoromethyl]phenyl)pyridine-3-carboxylic acid methyl ester (( \pm )-Bay K8644), tetraethylammonium chloride, and carbamylcholine chloride were all purchased from SigmaAldrich (Gillingham, UK). 2,5-dimethyl-4-[2-(phenyl methyl) benzoyl]-1H-pyrrole-3carboxylic acid methyl ester (FPL 64176) was obtained from Tocris (Abingdon, UK). All other reagents and salts used were from either VWR chemicals (Lutterworth, UK), or SigmaAldrich. The crude extract, hibiscus acid, and garcinia acid were prepared as $20 \mathrm{mg} / \mathrm{ml}$ stock solutions, dissolved in physiological salt solution (PSS), of the following composition (in 
$\mathrm{mM}$ ): $\mathrm{NaCl} 150, \mathrm{KCl} 5.4$, glucose 10, HEPES 10, $\mathrm{MgCl}_{2} 1.2$, and $\mathrm{CaCl}_{2} 1.8, \mathrm{pH}$ adjusted to 7.4 with $\mathrm{NaOH}$. Solutions of carbamylcholine chloride, tetraethylammonium chloride, and phenylephrine (all $100 \mathrm{mM}$ ) were prepared using PSS. Bay K8644 and FPL 64176 were dissolved in dimethyl sulfoxide (DMSO) as $10 \mathrm{mM}$ stock solutions, and subsequent dilutions were made using PSS. In the case of Bay K8644 and FPL 64176, the same dilutions of DMSO were used in the control experiments.

\subsection{Aorta tissue preparation and wire myography}

In-house bred male and female Sprague-Dawley rats (200-250 g) were sacrificed by cervical dislocation, and all studies were carried out in accordance with the guidelines and principles for the care and use of laboratory animals at the University of Strathclyde according to Schedule 1 of the Animals (Scientific Procedures) Act 1986. The thoracic and abdominal aorta was subsequently removed, and placed in cold PSS. Under a dissecting microscope (Nikon SMZ645), the aorta was cleaned of any adhering fat and loose connective tissue. The aorta was then cut into 4-5 mm long rings and mounted on intraluminal parallel wires; one of which was fixed and the other attached to a Grass FT03C force displacement transducer. The organ bath ( $1 \mathrm{ml}$ in volume) was filled with PSS and maintained at $37^{\circ} \mathrm{C}$ whilst being aerated with air. A resting tension of $1 \mathrm{~g}$ was applied to the tissue and a $1 \mathrm{~h}$ equilibration period was allowed, with regular reintroduction of fresh PSS and re-adjustment of the $1 \mathrm{~g}$ resting tension. The contractile response was acquired through a PowerLab 4/30 data acquisition system and recorded by Chart (v5.2) software (ADInstruments, Ltd., Oxfordshire, UK). Before commencing any experimental protocol the tissue was challenged repeatedly with $40 \mathrm{mM}$ $\mathrm{KCl}$ until the contractile responses were reproducible. 


\subsection{Effects of the crude methanolic extract of $\boldsymbol{H}$. sabdariffa on rat aorta}

In order to investigate the vasorelaxant activity, endothelium intact aorta sections were precontracted with $\mathrm{PE}(3 \mu \mathrm{M})$ or $\mathrm{KCl}(60 \mathrm{mM})$. Once the contractions were stable, $0.001-1$ $\mathrm{mg} / \mathrm{ml}$ crude extract of $H$. sabdariffa was added in a cumulative manner to the tissues precontracted with $\mathrm{PE}$, and $0.01-2 \mathrm{mg} / \mathrm{ml}$ crude extract was used in the tissues pre-contracted with $\mathrm{KCl}$.

\subsection{Effects of hibiscus and garcinia acid on rat aorta}

As per the protocol described above for the crude extract, $0.001-1 \mathrm{mg} / \mathrm{ml}$ hibiscus or garcinia acid was added in a cumulative manner to the tissues pre-contracted with PE, and 0.01-2 $\mathrm{mg} / \mathrm{ml}$ hibiscus or garcinia acid was used in the tissues pre-contracted with $\mathrm{KCl}$.

The majority of the experiments were carried out on endothelium-intact aortas, unless otherwise indicated. Confirmation that the endothelium was intact was demonstrated by a greater than $70 \%$ relaxation in response to carbachol $(10 \mu \mathrm{M})$, when the aorta was precontracted with PE $(3 \mu \mathrm{M})$. The influence of the endothelium on the relaxant response of either hibiscus or garcinia acid was examined, and this was established by examining their effect in denuded preparations. The endothelium was denuded by gently rubbing the luminal surface of the aortic ring with a sanded down wooden cocktail stick. The absence of the endothelium was confirmed by less than $10 \%$ relaxation in response to carbachol $(10 \mu \mathrm{M})$, in aorta pre-contracted with PE $(3 \mu \mathrm{M})$.

\subsection{Role of L-type voltage dependent calcium channels (VDCCs) on hibiscus and garcinia acid induced relaxation}

To establish whether hibiscus and garcinia acid produce their relaxation by inhibiting L-type voltage dependent calcium channels (VDCCs), their effect on the contractions produced by FPL 64176, a benzopyrrole-type agonist of L-type $\mathrm{Ca}^{2+}$ channels [22] or Bay K 8644 [23] 
was examined. The tissue was initially depolarised with $20 \mathrm{mM} \mathrm{KCl}$ for $5 \mathrm{~min}$, to activate VDCCs and produce a minimal contractile response. Thereafter, FPL $64176(30 \mu \mathrm{M})$ or Bay $\mathrm{K} 8644(0.1 \mu \mathrm{M})$ was added in order to produce further activation of VDCCs [22, 24]. Once the contractile response had stabilised, either hibiscus acid or garcinia acid, was applied in concentrations $0.5-1 \mathrm{mg} / \mathrm{ml}$.

\subsection{Effect of hibiscus and garcinia acid on the release of intracellular $\mathrm{Ca}^{2+}$}

A component of the contractile response to PE involves $\mathrm{Ca}^{2+}$ release from the sarcoplasmic reticulum (SR), which produces a phasic contractile response [25]. To examine the effect of hibiscus and garcinia acid on $\mathrm{SR} \mathrm{Ca}^{2+}$ release a control contractile response to $\mathrm{PE}(3 \mu \mathrm{M})$ in regular PSS was initially obtained. After a $1 \mathrm{~h}$ recovery period, the tissue was exposed to a $\mathrm{Ca}^{2+}$ free physiological solution containing $1 \mathrm{mM}$ ethylene glycol-bis ( $\beta$-aminoethyl ether)$\mathrm{N}, \mathrm{N}, \mathrm{N}^{\prime}, \mathrm{N}^{\prime}$-tetraacetic acid (EGTA) for $15 \mathrm{~min}$. During this period, either vehicle, hibiscus or garcinia acid was applied and the tissue was subsequently re-challenged with PE $(3 \mu \mathrm{M})$.

\subsection{Effect of hibiscus and garcinia acid on the influx of extracellular $\mathrm{Ca}^{2+}$}

Another component of the contractile response to $\mathrm{PE}$ involves $\mathrm{Ca}^{2+}$ influx from the extracellular space, which produces the sustained (tonic) phase of the contractile response [25]. To determine the effect of hibiscus and garcinia acid on the tonic phase of contraction, the tissue was exposed to a $\mathrm{Ca}^{2+}$ free physiological solution containing $1 \mathrm{mM}$ EGTA for 15 min, the tissue was then challenged with $\mathrm{PE}(3 \mu \mathrm{M})$ for 5 min to produce the phasic contractile response. Thereafter, $1.8 \mathrm{mM} \mathrm{Ca}^{2+}$ (producing a free calcium concentration 0.8 $\mathrm{mM}$ as calculated using the MAXC computer program), was reintroduced to the bath, resulting in a tonic contraction Hibiscus or garcinia acid $(0.5 \mathrm{mg} / \mathrm{ml})$ was applied during the tonic phase of the contraction. 


\subsection{Effect of blocking potassium channels on the relaxant activity of hibiscus and garcinia acid}

To establish whether the relaxation to hibiscus or garcinia acid involves the activation of $\mathrm{K}^{+}$ channels, their effect was examined in the presence of the non-selective $\mathrm{K}^{+}$channel blocker tetraethyl ammonium chloride (TEA) [26]. The aorta was challenged with PE (3 $\mu \mathrm{M})$ alone, and $0.001-1 \mathrm{mg} / \mathrm{ml}$ hibiscus or garcinia acid was added as described above. Then, and after 1 h recovery, the aorta was preincubated with $6 \mathrm{mM}$ TEA for $20 \mathrm{~min}$ prior to pre-contraction with PE $(3 \mu \mathrm{M})$, and once the contractile response had stabilised, hibiscus or garcinia acid was applied to the tissue in a cumulative manner.

\section{Statistical analysis}

For the contractile responses, the data were expressed as percentage of maximum contraction to either agonists or $\mathrm{KCl}$. Relaxation of the tissues is expressed as the measured tension following the addition of hibiscus acid or garcinia acid divided by the steady state tension produced by the contractile stimulus being used, x100. Nonlinear regression analysis (GraphPad Prism version 7, San Diego, CA, USA) was used for fitting the log concentrationresponse curve and determination of the $\mathrm{IC}_{50}$ (concentration required to produce $50 \%$ of the maximum inhibitory effect) and $I_{\max }$ (the maximum inhibitory effect). One tissue that was pre-contracted always served as a control. All data are presented as mean \pm standard error of the mean (s.e.m.). The number of observations are expressed in the format of $n=N / n$ where $N$ is the number of tissues and $n$ is the number of animals. One-way ANOVA with Tukey's multiple comparisons test was used to compare the treatments with control groups, and Student's two-tailed unpaired $t$-test was applied for statistical comparison of $\mathrm{IC}_{50}$ of different groups. $\mathrm{P}<0.05$ was considered to be statistically significant. 


\section{Results}

\subsection{Effect of the crude extract of $H$. sabdariffa on the rat aorta}

The crude methanolic extract of $H$. sabdariffa produced a concentration-dependent relaxation of endothelium-intact rat aorta pre-contracted with PE $(3 \mu \mathrm{M})$. The $\mathrm{IC}_{50}$ for the crude extract was $0.33 \pm 0.04 \mathrm{mg} / \mathrm{ml}$ (Figure $2 \mathrm{~A}$ ) and the highest concentration tested $(1 \mathrm{mg} / \mathrm{ml})$ relaxed the tissue by $76 \pm 4 \%(n=12 / 4)$. The crude extract also produced a concentration-dependent relaxation of the aorta when it was pre-contracted with $\mathrm{KCl}(60 \mathrm{mM})$ with an $\mathrm{IC}_{50}$ of $1.5 \pm$ $0.5 \mathrm{mg} / \mathrm{ml} ; \mathrm{n}=16 / 4$. At $1 \mathrm{mg} / \mathrm{ml}$ the crude extract produced relaxation of $33 \pm 2 \%$ when it was applied to the aorta pre-contracted with $\mathrm{KCl}(60 \mathrm{mM})$, and this was increased to $68 \pm 2 \%$ at the highest concentration examined $(2 \mathrm{mg} / \mathrm{ml})$ (Figure $2 \mathrm{~B})$.

\subsection{Effect of hibiscus and garcinia acid on the rat aorta}

Hibiscus acid caused a concentration-dependent relaxation of the aorta pre-contracted with PE $(3 \mu \mathrm{M})$. The $\mathrm{IC}_{50}$ for hibiscus acid was $0.09 \pm 0.01 \mathrm{mg} / \mathrm{ml}$ (Figure 3A) in the endothelium-intact aorta and the highest concentration tested $(1 \mathrm{mg} / \mathrm{ml})$ almost completely relaxed the tissue $(96 \pm 2 \%$ relaxation) $(n=18 / 6)$. The relaxation was maintained for as long as hibiscus acid was present, and the tissue showed complete recovery in response to PE after washing it out and allowing approximately $60 \mathrm{~min}$ for recovery. The time control for these experiments showed a slight relaxation $(15 \pm 4 \%)$ in the PE-induced contraction, over the time course of the experiment.

When the endothelium was removed, the magnitude of contraction produced by PE increased by $27 \%(n=32 / 8)$ compared to that induced in intact aorta. The relaxant effect of hibiscus acid was also examined on endothelium-denuded aorta, where the magnitude of the relaxation was similar $(89 \pm 3 \%)(n=9 / 6)$; but there was a 2 -fold shift to the right with regard 
to the sensitivity to hibiscus acid, yielding an $\mathrm{IC}_{50} 0.19 \pm 0.02 \mathrm{mg} / \mathrm{ml}(\mathrm{P}<0.001$ compared to endothelium intact) (Figure 3Aii). It was also evident that the lowest concentration of hibiscus acid tested $(1 \mathrm{mg} / \mathrm{ml})$ had no relaxant effect in the denuded aorta, whereas it caused $10 \pm 2 \%$ relaxation in the endothelium intact aorta. In tissues that had been denuded of endothelium, which served as a time control, there was a slight increase in the PE-induced contraction of $5 \pm 9 \%$ over the course of the experiment.

Garcinia acid was found to have a similar effect to that of hibiscus acid, showing almost complete relaxation in both endothelium intact and denuded aorta. The maximum relaxation to garcinia acid was similar irrespective of whether the endothelium was intact $(94 \pm 2 \%)$ or denuded $(92 \pm 2 \%)$. However, the $\mathrm{IC}_{50}$ value for garcinia acid was significantly higher in the endothelium denuded aorta $(0.2 \pm 0.02 \mathrm{mg} / \mathrm{ml} ; \mathrm{n}=9 / 6)$ compared to the endothelium intact preparation $(0.12 \pm 0.01 \mathrm{mg} / \mathrm{ml} ; \mathrm{P}<0.001 ; \mathrm{n}=18 / 6)$ (Figure 3B). In comparing the relaxant activities of both hibiscus and garcinia acids, there was no significant difference between the diastereomers to antagonise the PE-induced contraction. 
$\mathrm{Ai}$

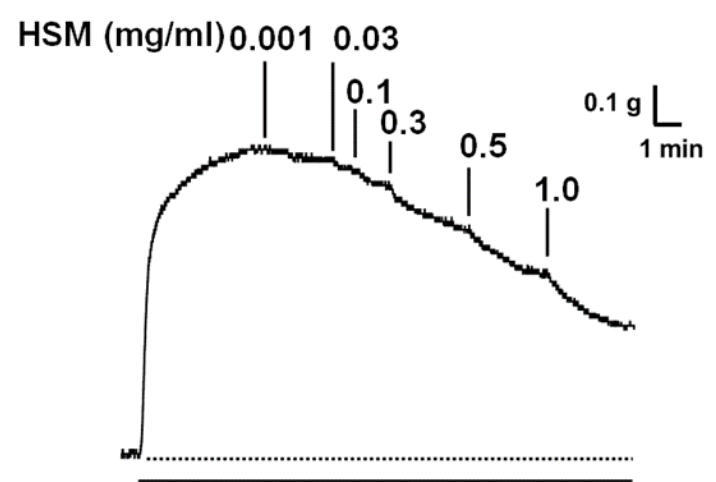

PE $3 \mu \mathrm{M}$ ii

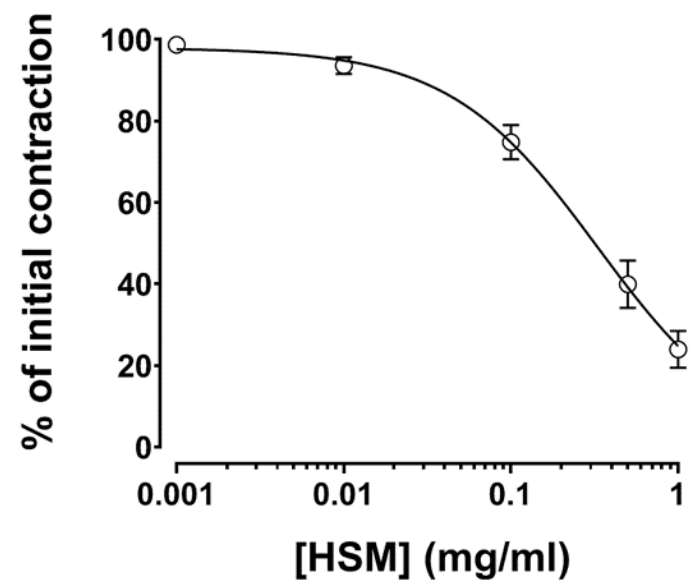

ii

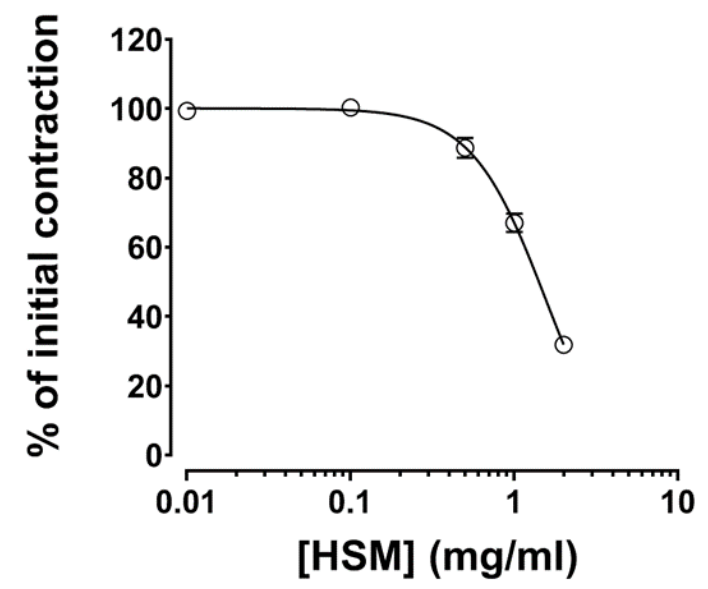

Figure 2: Relaxant effect of the crude methanolic extract of $H$. sabdariffa (HSM) on the rat aorta. Representative recordings of the effect of HSM on endothelium-intact rat aorta pre-contracted with $\mathrm{PE}(3 \mu \mathrm{M})(\mathbf{A i})$, and $\mathrm{KCl}(60 \mathrm{mM})(\mathbf{B i})$. Summary figures of the relaxation due to $\mathrm{HSM}$ on the aorta pre-contracted with $\mathrm{PE}$ (Aii), and $\mathrm{KCl}$ (Bii). The relaxation is expressed as a percentage of the initial contraction. Data represent mean \pm s.e.m. ( $\mathrm{n}=12 / 4$ for $\mathrm{PE}$ pre-contraction and $\mathrm{n}=16 / 4$ for $\mathrm{KCl}$ pre-contraction). 
When the aorta was pre-contacted with $\mathrm{KCl}(60 \mathrm{mM})$, hibiscus acid also produced a concentration-dependent relaxation. The $\mathrm{IC}_{50}$ was $0.57 \pm 0.06 \mathrm{mg} / \mathrm{ml} ; \mathrm{n}=12 / 6$ and the highest concentration of hibiscus acid examined $(2 \mathrm{mg} / \mathrm{ml}$ ) produced a relaxation of $77 \pm 5 \%$ (Figure 4A). When the endothelium was removed, there was no change in the sensitivity of the aorta to hibiscus acid $\left(\mathrm{IC}_{50}\right.$ was $\left.0.66 \pm 0.1 \mathrm{mg} / \mathrm{ml} ; \mathrm{n}=6 / 4\right)$ or the magnitude of the relaxation obtained at the highest concentration examined $(72 \pm 6 \%)$ (Figure $4 \mathrm{~A})$.

Similarly, garcinia acid also relaxed the aorta pre-contracted with $\mathrm{KCl}$ (Figure 4B). As with hibiscus acid, there was no significant effect of removing the endothelium on the $\operatorname{IC}_{50}(0.38 \pm$ $0.06 \mathrm{mg} / \mathrm{ml} ; \mathrm{n}=13 / 6$ for intact and $0.45 \pm 0.08 \mathrm{mg} / \mathrm{ml} ; \mathrm{n}=10 / 4$ for denuded), or the magnitude of the relaxation produced by garcinia acid at the highest concentration tested $(77 \pm 5 \%$ and $72 \pm 5 \%$, respectively). Over the course of these experiments the time control showed a $20 \pm$ $4 \%$ increase in the contractile response to $\mathrm{KCl}$ in the endothelium intact preparation and a 22 $\pm 3 \%$ increase in the endothelium-denuded preparation. There was no significant difference between hibiscus acid and garcinia acid in their ability to relax the $\mathrm{KCl}$ contraction. However, the concentration of either hibiscus or garcinia acid that was needed to relax the $\mathrm{KCl}$-induced contractions was significantly higher $(\mathrm{P}<0.01)$ than that required to relax the PE-induced contractions.

\subsection{Relaxant effect of hibiscus or garcinia acid on contraction induced by L- type calcium channel activators}

Since hibiscus and garcinia acid relaxed the aorta pre-contracted with $\mathrm{KCl}$, and the contraction induced by $\mathrm{KCl}$ is primarily dependent on the activation of voltage-dependent

$\mathrm{Ca}^{2+}$ channels (VDCCs), one possible mechanism to explain their vasorelaxant activity is through inhibition of VDCCs. To examine this further, the effect of these substances on the contractions induced by $\mathrm{Ca}^{2+}$ channel activators was examined. 
$\mathrm{Ai}$

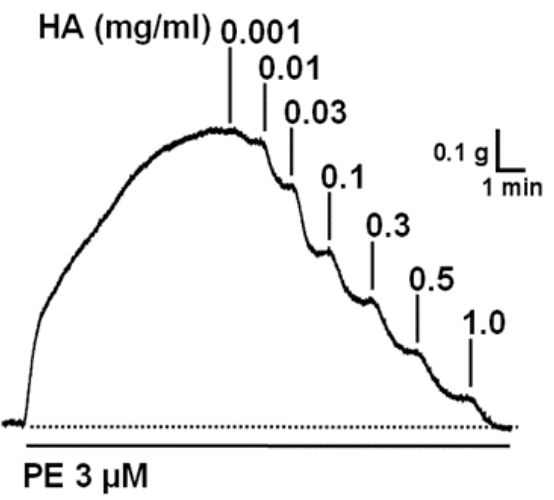

$\mathrm{Bi}$

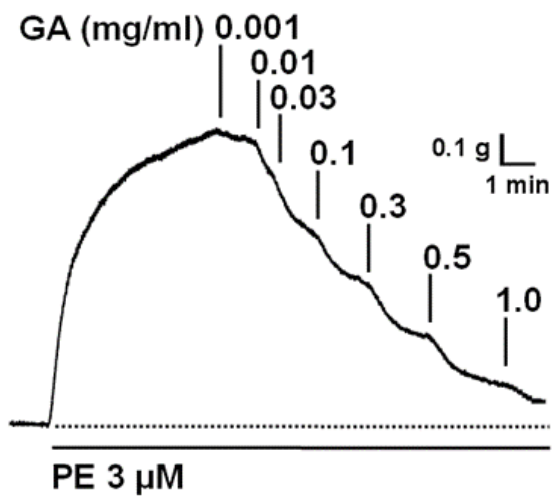

ii

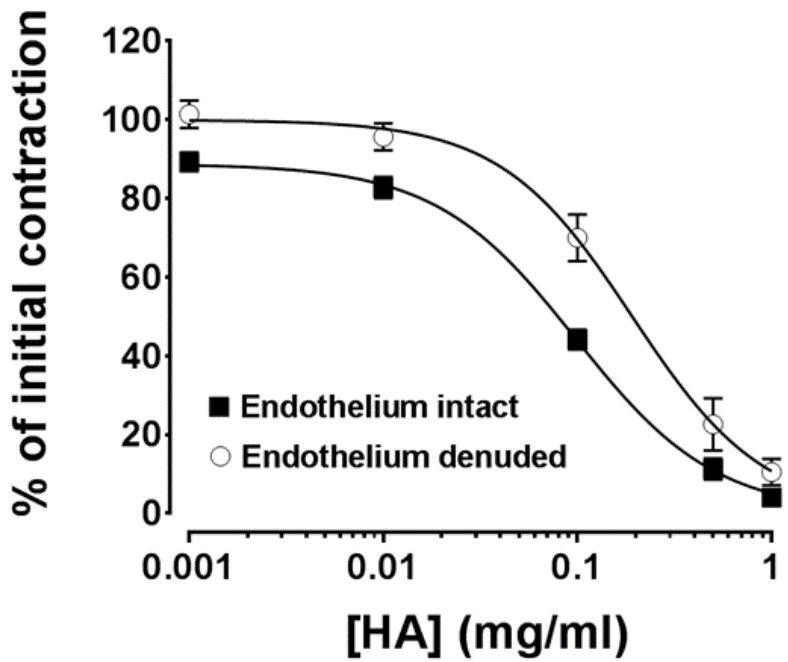

ii

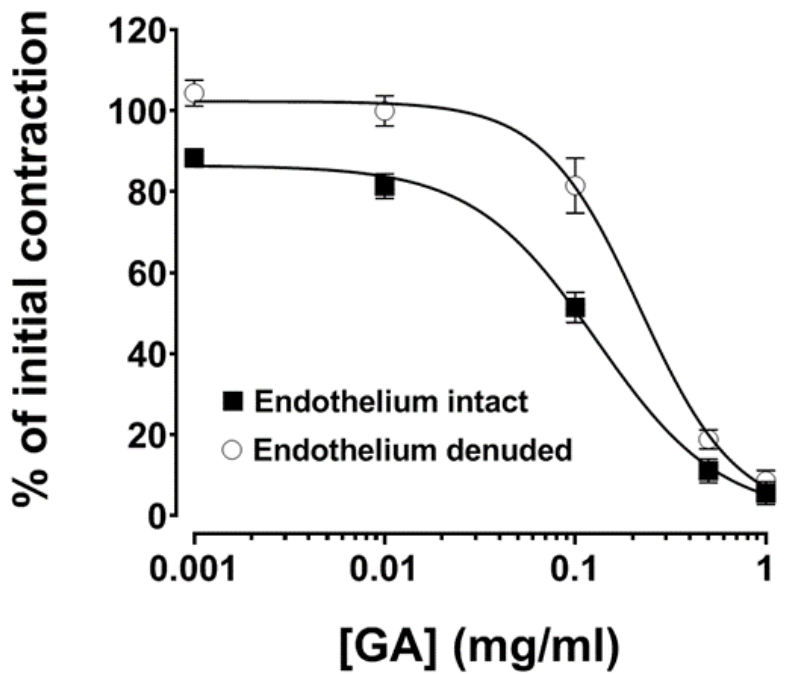

Figure 3: Relaxant effect of hibiscus acid and garcinia acid on the rat aorta precontracted with PE. Representative recordings of the effect of $\mathrm{HA}$ (Ai) and GA (Bi) on the endothelium-intact aorta pre-contracted with PE $(3 \mu \mathrm{M})$. Relaxant effect of HA (Aii) and GA (Bii) on PE-induced contraction of endothelium-intact and endothelium-denuded aortic rings. The relaxation is expressed as a percentage of the initial contraction. Data represent mean \pm s.e.m. ( $n=18 / 6$ for the intact aortic rings and $n=9 / 6$ for the denuded rings). 
$\mathrm{Ai}$

$\mathrm{HA}(\mathrm{mg} / \mathrm{ml}) 0.1$

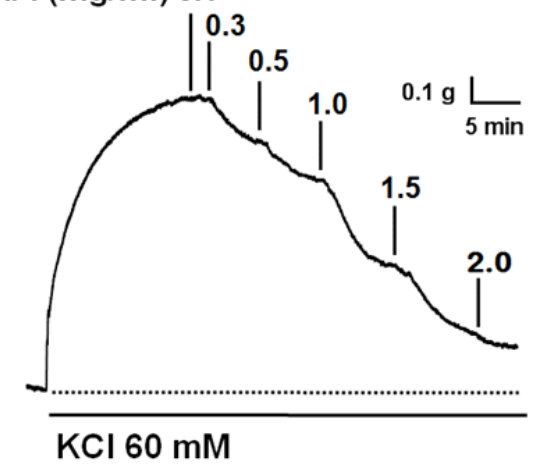

$\mathrm{Bi}$

$\mathrm{GA}(\mathrm{mg} / \mathrm{ml}) 0.1$

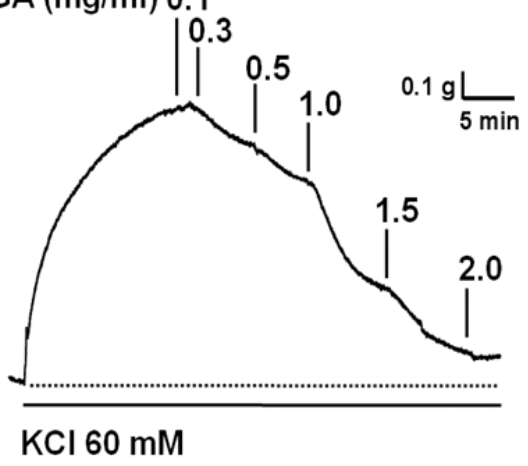

ii

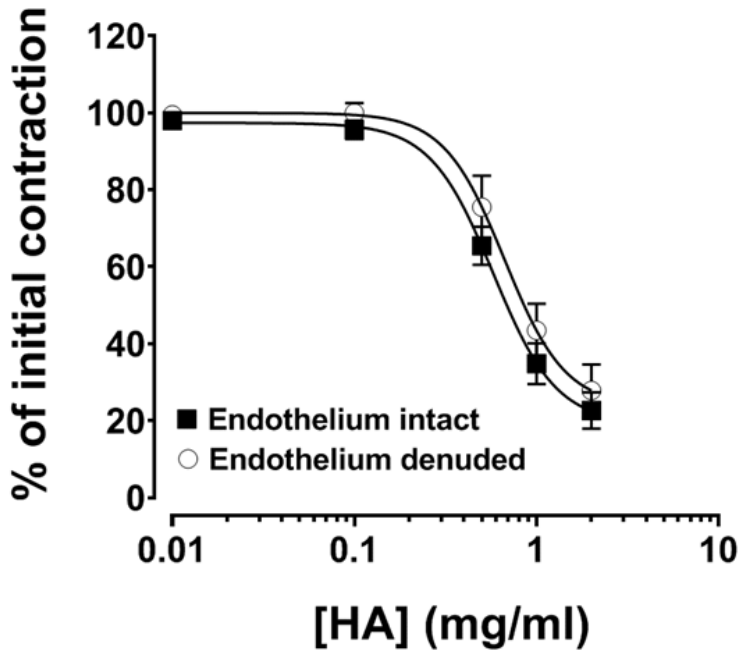

ii

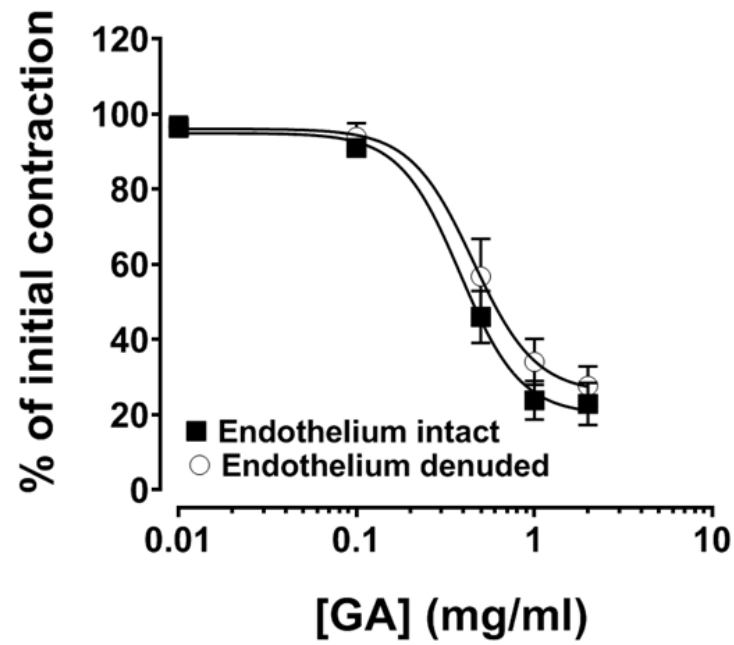

Figure 4: Relaxant effect of hibiscus acid and garcinia acid on the rat aorta precontracted with KCl. Representative recording of the effect of HA (Ai) and GA (Bi) on the endothelium-intact aorta pre-contracted with $\mathrm{KCl}(60 \mathrm{mM})$. Relaxant effect of HA (Aii) and GA (Bii) on KCl-induced contraction of endothelium-intact and endothelium-denuded aortic rings. The relaxation is expressed as a percentage of the initial contraction. Values represent mean \pm s.e.m. ( $n=12-13 / 6$ for the intact aortic rings and $n=6-10 / 4$ for the denuded rings). 
All the aortas pre-contracted with a low concentration of $\mathrm{KCl}$ followed the addition of either FPL 64176 or Bay K 8644, showed an oscillatory type of contractile response.

When the aorta was pre-contracted with FPL $64176(30 \mu \mathrm{M})$, hibiscus acid $(0.5 \mathrm{mg} / \mathrm{ml})$ almost completely relaxed the tissue $(95 \pm 2 \%$ relaxation; $n=4 / 4)$. A similar effect was observed when Bay K $8644(0.1 \mu \mathrm{M})$ was used to contract the aorta, although in this case a higher concentration of hibiscus acid $(1 \mathrm{mg} / \mathrm{ml})$ was required to produce a similar degree of relaxation $(94 \pm 4 \%$; $=4 / 4)$ (Figure 5). The effect of garcinia acid $(0.5 \mathrm{mg} / \mathrm{ml})$ was very similar to that of hibiscus acid; producing $94 \pm 4 \%(n=4 / 4)$ relaxation of the aorta precontracted with FPL 64176 and requiring a higher concentration $(1 \mathrm{mg} / \mathrm{ml})$ to almost completely relax the aorta $(93 \pm 2 \%$; $=4 / 4)$ when pre-contracted with Bay K 8644 (Figure $5)$.

\subsection{Effect of hibiscus and garcinia acid on the phasic and tonic contractions induced by $P E$ in the rat aorta}

In the absence of extracellular calcium, the phasic contraction of the aorta induced by PE is due to the release of intracellular calcium from intracellular stores [25]. Under $\mathrm{Ca}^{2+}$-free conditions, PE $(3 \mu \mathrm{M})$ produced a transient contraction, which was $23 \pm 1 \%$ of the contraction produced by PE in $\mathrm{Ca}^{2+}$ containing PSS (Figure 6). Neither hibiscus nor garcinia acid $(1 \mathrm{mg} / \mathrm{ml})$ had any significant effect on the transient contraction to PE in $\mathrm{Ca}^{2+}$-free PSS, being $16 \pm 3 \%$ and $15 \pm 1 \%$ in the presence of the respective acids $(n=4 / 4)$ (Figure 6). After an initial phasic contraction to PE $(3 \mu \mathrm{M})$ was obtained in $\mathrm{Ca}^{2+}$-free PSS, this developed into a sustained contraction following the subsequent re-addition of $\mathrm{Ca}^{2+}$ to the PSS. When hibiscus acid (Figure 7A) or garcinia acid (Figure 7B) was added during the sustained phase of the contraction, it caused a relaxation of $71 \pm 3 \%$ and $76 \pm 5 \%$, respectively $(n=4 / 4)$ (Figure 7C). 
A

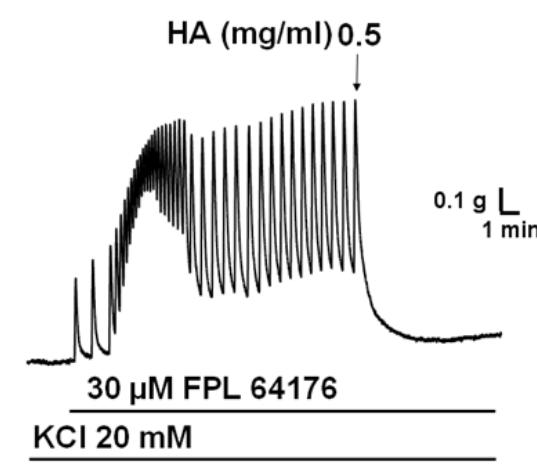

C

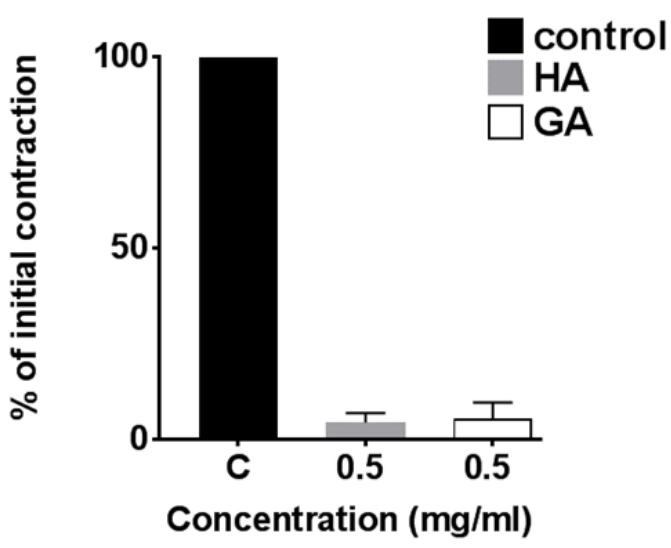

B

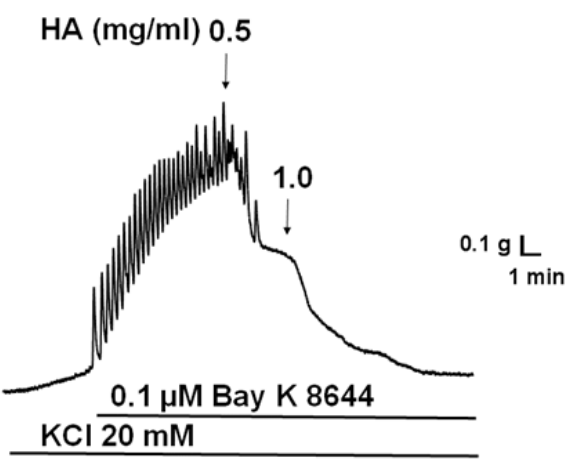

D

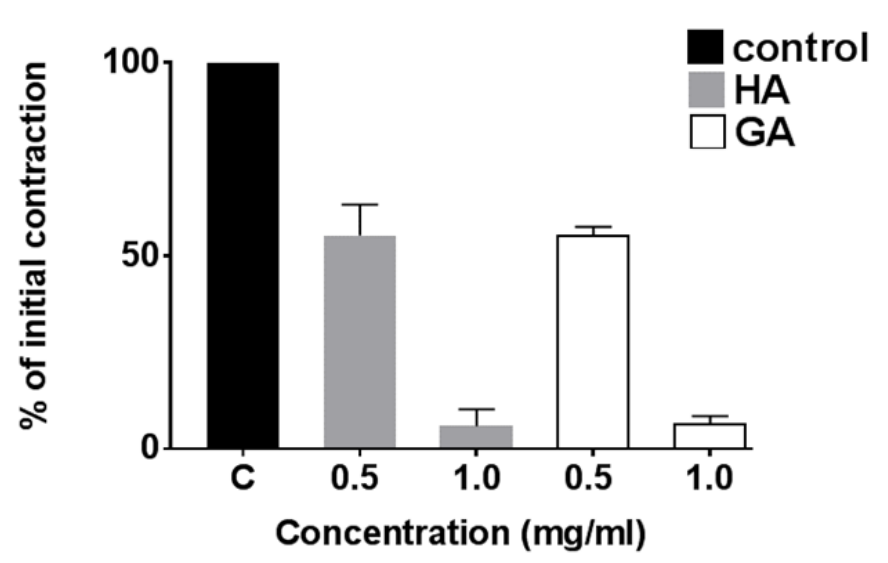

Figure 5: Relaxant effect of hibiscus acid and garcinia acid, on the rat aorta precontracted with L-type calcium channel activators. Representative recording of the effect of HA $(0.5-1 \mathrm{mg} / \mathrm{ml})$ on the contraction induced by $30 \mu \mathrm{M}$ FPL 64176 (A) or $0.1 \mu \mathrm{M}$ Bay K 8644 (B). Summary figures of the relaxation due to HA and GA when the aorta was precontracted with either FPL 64176 (C) or Bay K 8644 (D). Data represent mean \pm s.e.m. $(n=4 / 4)$. 
A
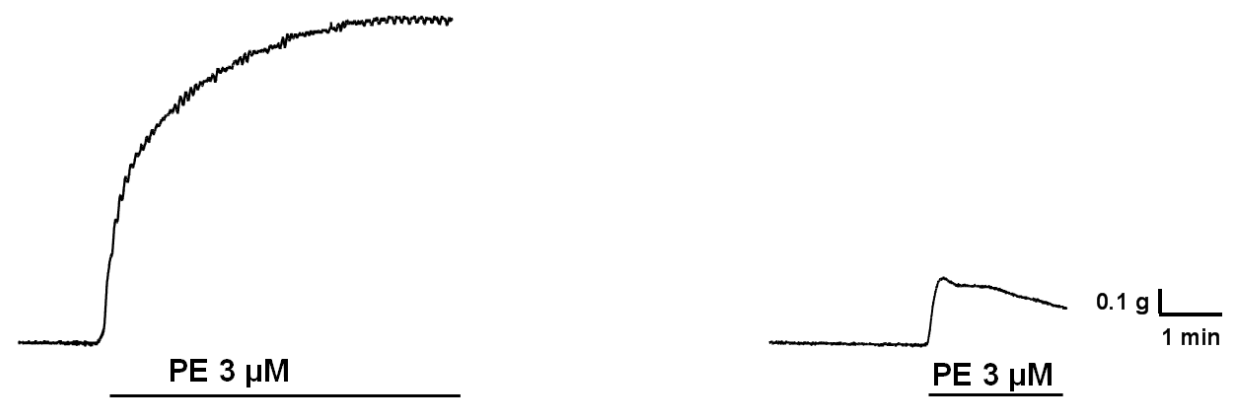

PE $3 \mu \mathrm{M}$

$\mathrm{Ca}^{2+}-$ free PSS

B
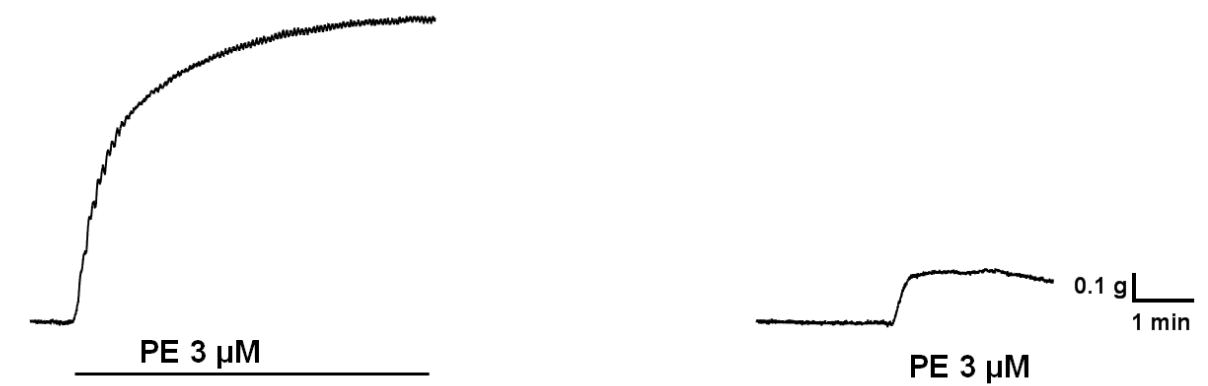

PE $3 \mu \mathrm{M}$

$1 \mathrm{mg} / \mathrm{ml} \mathrm{HA}$

$\underline{\mathrm{Ca}^{2+}-\text { free PSS }}$

C

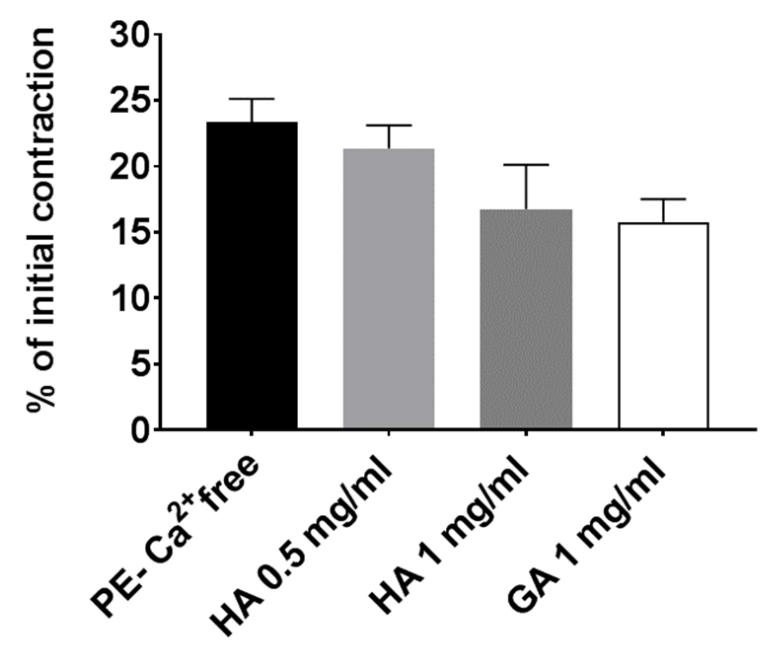

Figure 6: Effect of hibiscus acid and garcinia acid on the phasic component of contraction induced by PE $(3 \mu \mathrm{M})$ in the rat aorta. Representative control recording of the PE-induced contraction in the presence and absence of extracellular $\mathrm{Ca}^{2+}(\mathrm{A})$. The effect of $\mathrm{HA}(1 \mathrm{mg} / \mathrm{ml})$ on the PE-induced contraction in the absence of extracellular $\mathrm{Ca}^{2+}$ (B). (C) Summary figure showing the effects of HA $(0.5 \mathrm{and} 1 \mathrm{mg} / \mathrm{ml})$ and GA $(1 \mathrm{mg} / \mathrm{ml})$ on the PEinduced transient contraction of the aorta. Data represent mean \pm s.e.m. $(n=4 / 4)$. 
A

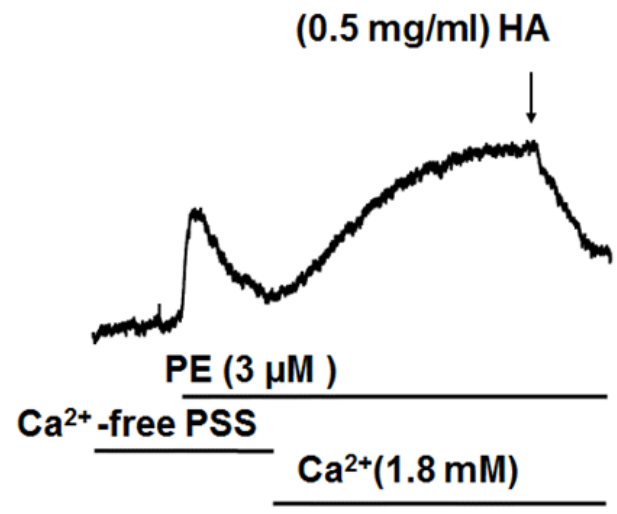

C

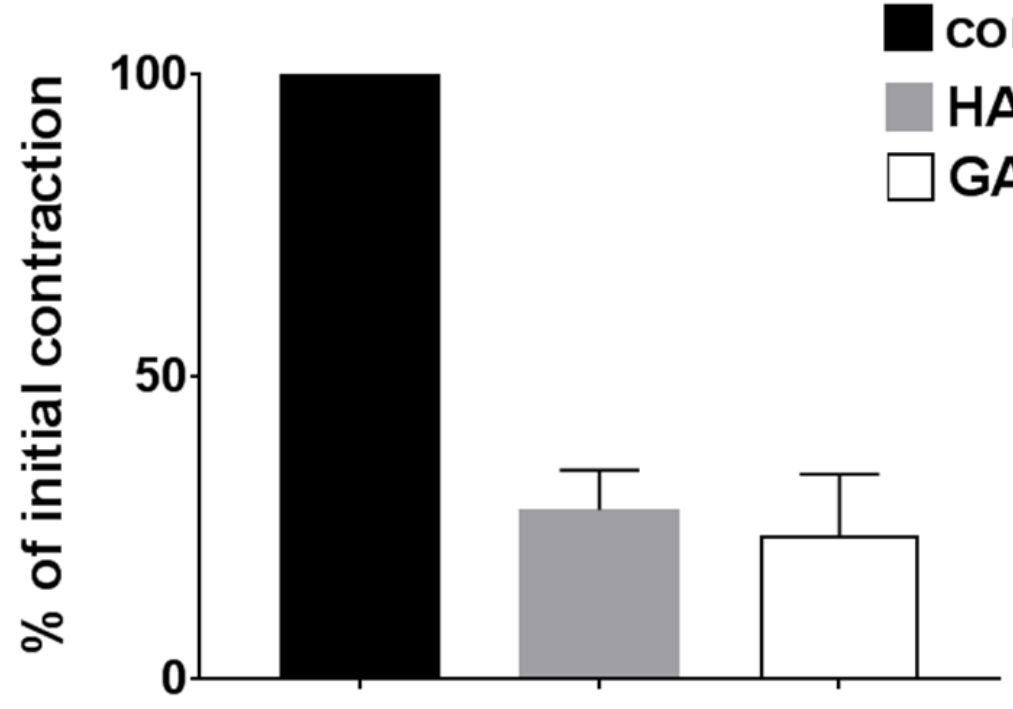

(0.5 mg/ml) GA

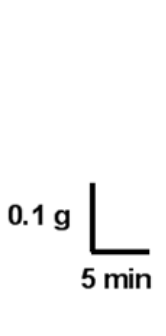

B

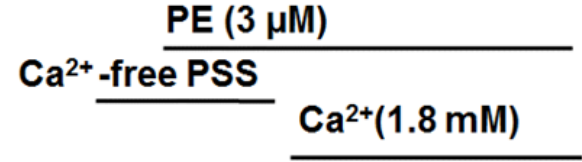

Figure 7: Relaxant effect of hibiscus and garcinia acid on the sustained component of the PE-induced contraction. Representative recordings showing the effect of hibiscus acid (A) and garcinia acid (B) on the tonic component of the PE-induced contraction, following the addition of $1.8 \mathrm{mM} \mathrm{Ca}^{2+}$. The intracellular store was depleted by the application of $\mathrm{PE}$ in a $\mathrm{Ca}^{2+}$ free medium and the re-addition of $\mathrm{Ca}^{2+}$ produced the tonic phase of contraction. (C) Summary figure showing the effects of HA and GA $(0.5 \mathrm{mg} / \mathrm{ml})$ on the tonic component of the PE-induced contraction. Values represent mean \pm s.e.m. $(n=4 / 4)$. 


\subsection{Effect of a potassium channel blocker on the relaxant effect of hibiscus and garcinia}

acid

Participation of $\mathrm{K}^{+}$channels in the relaxant effect of hibiscus or garcinia acid was also examined, using the non-selective potassium channel blocker (TEA). Pre-incubation of the aorta with TEA (6 mM) increased the magnitude of PE-induced contraction by $34 \%(\mathrm{n}=13 / 7)$ when compared to that produced in the absence of TEA. The $\mathrm{IC}_{50}$ for hibiscus acid induced relaxation of the PE pre-contracted aorta was significantly $(\mathrm{P}<0.05)$ increased from $0.09 \pm$ $0.01 \mathrm{mg} / \mathrm{ml}$ under control conditions to $0.3 \pm 0.04 \mathrm{mg} / \mathrm{ml}$ in the presence of TEA, and the maximum relaxation was slightly reduced from $95 \pm 4 \%$ to $82 \pm 5 \%$; $=6 / 6$ ) (Figure $8 \mathrm{~A}$ ). A similar effect of TEA was observed when garcinia acid was used as the vasorelaxant. Specifically, TEA significantly $(\mathrm{P}<0.05)$ increased the $\mathrm{IC}_{50}$ for garcinia acid from $0.13 \pm 0.02$ $\mathrm{mg} / \mathrm{ml}$ to $0.25 \pm 0.03 \mathrm{mg} / \mathrm{ml}$ and reduced the maximum relaxation from $93 \pm 4 \%$ to $86 \pm 2 \%$; $\mathrm{n}=7 / 6)$ (Figure $8 \mathrm{~B})$. 
A

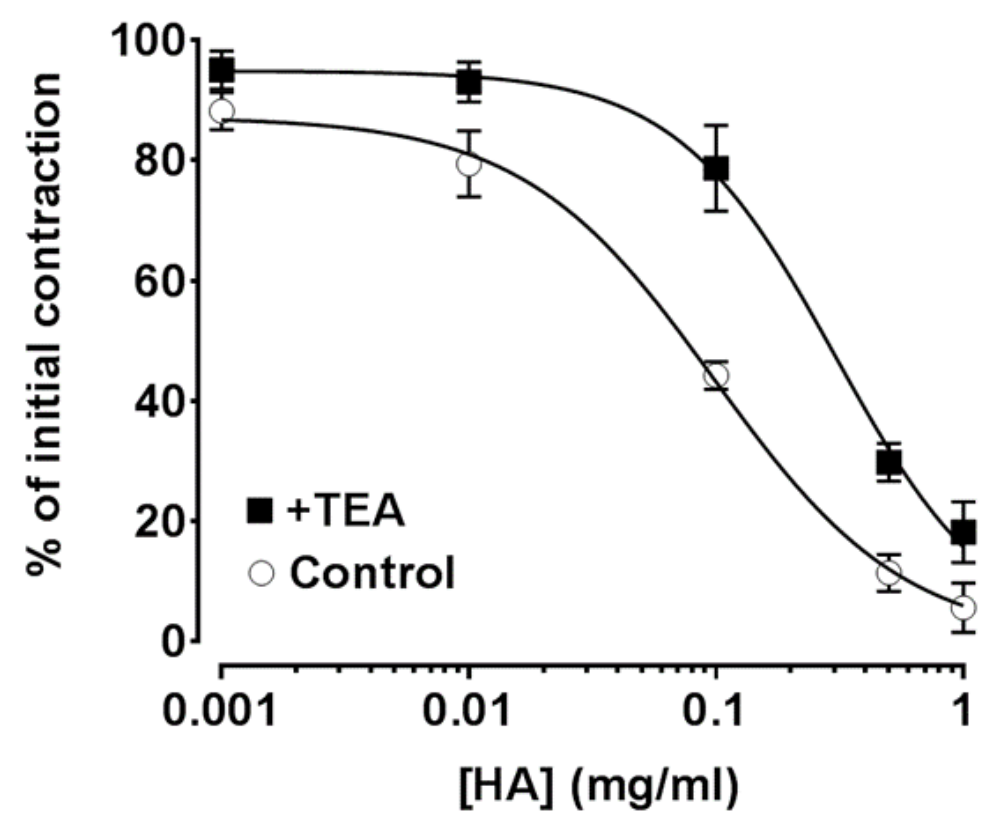

B

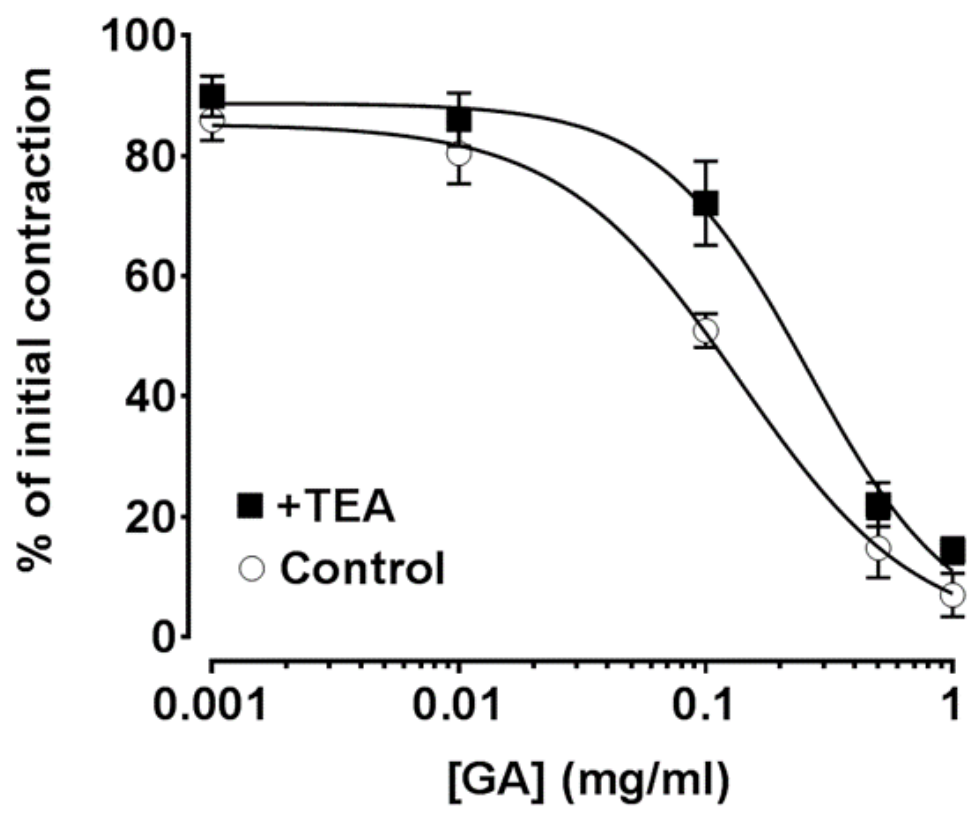

Figure 8: The effect of potassium channel blockade on the relaxation induced by hibiscus or garcinia acid on the PE pre-contracted rat aorta. Relaxant effect of HA (A) and GA (B) on the PE pre-contracted endothelium-intact aorta in presence and absence of TEA $(6 \mathrm{mM})$. The relaxation is expressed as a percentage of the initial contraction. Data represent mean \pm s.e.m. ( $\mathrm{n}=6 / 6$ for $\mathrm{HA}$ and $7 / 6$ for $\mathrm{GA}$ ). 


\section{Discussion}

There is considerable evidence in the literature that $H$. sabdariffa has an antihypertensive effect and this is further supported by a number of in vitro studies demonstrating a vasorelaxant effect of the crude extract of this plant $[14-18,27,28]$. This study demonstrated the vasorelaxant activity of the crude methanolic extract of H.sabdariffa calyces on the rat aorta, and it was found to be significantly more potent in its relaxant effect when the tissue was pre-contracted with $\mathrm{PE}$ compared to $\mathrm{KCl}$. These results are in agreement with what has been reported previously [17], where the crude methanolic extract at a concentration of 1 $\mathrm{mg} / \mathrm{ml}$ produced $\sim 30 \%$ relaxation when the aorta was pre-contracted with $\mathrm{KCl}$, and $\sim 80 \%$ relaxation when it was pre-contracted with PE.

Using a bio-assay guided fractionation process, this study has now shown that hibiscus acid, one of the constituents isolated and identified from the calyces of $H$. sabdariffa has a direct vasorelaxant effect on the rat aorta, which may, at least in part, be the constituent responsible for the vascular activity of this plant. With regard to the vasorelaxant effect of hibiscus acid, it was found to be more potent and efficacious when compared to the activity of the crude extract. The complementary finding that commercially available garcinia acid, which is the main organic acid found in Garcinia cambogia (G. cambogia) (Clusiaceae), had a very similar effect, provides further support for the notion that hibiscus acid has vasorelaxant activity. Both hibiscus and garcinia acid produced a concentration-dependent relaxation of the aorta when it was pre-contracted with either PE or $\mathrm{KCl}$. Their effects were fully reversed upon their washout indicating that, over the concentration range used, they had no deleterious effect on the tissue. Both hibiscus and garcinia acid were found to be significantly more potent in their relaxant effect when the tissue was pre-contracted with PE, when compared to 
pre-contraction with $\mathrm{KCl}$. A similar finding was observed with the crude methanolic extract of H. sabdariffa [17].

Removal of the endothelium did not prevent the relaxation of the aorta to either hibiscus or garcinia acid in the PE pre-contracted aorta, with a similar degree of relaxation being achieved in endothelium intact and endothelium denuded tissues. Whilst this indicates that the relaxation to both these substances is endothelium independent there was nevertheless a slight rightward shift in the concentration-response curve to both hibiscus and garcinia acid after removal of the endothelium. This may indicate a modulatory role of the endothelium in the response to either hibiscus or garcinia acid. However, it may also have been a consequence of the increased contraction produced by PE when the endothelium was removed, a finding that has previously been reported by others [29]. When the aorta was precontracted with $\mathrm{KCl}$, there was no effect of removing the endothelium on the relaxation produced by either hibiscus or garcinia acid, and in this case the contractile response to $\mathrm{KCl}$ was not significantly affected by removal of the endothelium either. It should be noted that previous studies with the crude extracts of $H$. sabdariffa have found that the relaxation is significantly affected by removal of the endothelium $[15,17,18]$, thus, it is clear that there could be additional constituents in the crude extract that are affecting vascular activity.

As both hibiscus and garcinia acid produced relaxation of the rat aorta pre-contracted with $\mathrm{KCl}$, one possible explanation for their observed effect is that they are blocking $\mathrm{Ca}^{2+}$ channels. This is because the contraction induced by $\mathrm{KCl}$ predominantly involves depolarisation of the smooth muscle cell membrane potential and the resultant activation of VDCCs. Indeed, the relaxation of this type of contraction is frequently utilised when studying the effect of VDCC blockers [24, 30-35]. Further support for this mechanism of action is 
provided by the studies showing that hibiscus and garcinia relaxed the aorta when it was precontracted with the selective L-type $\mathrm{Ca}^{2+}$ channel activator FPL 64176 or Bay K8644 [36, 37]. The contraction induced by FPL 64176 was completely relaxed by lower concentrations of hibiscus or garcinia acid than what was required when Bay K8644 was used to precontract the tissue. A possible explanation for the difference in sensitivity may be related to the agonistic properties of FPL 64176 and Bay K8644, as both L-type $\mathrm{Ca}^{2+}$ channel activators act via a mechanism and site of action that is unique for each [22, 37]. The findings are nevertheless consistent with what has been observed previously with classical L-type $\mathrm{Ca}^{2+}$ channel blockers such as nifedipine, diltiazem, and verapamil [22, 38]. Interestingly, these selective L-type $\mathrm{Ca}^{2+}$ channel activators produced an oscillatory contractile response in the aorta, which is similar to what has been previously reported by Auguet et al., (1988). It also appeared that hibiscus and garcinia acid were more effective at relaxing the contractions induced by the $\mathrm{Ca}^{2+}$ channel activators compared to those induced by $\mathrm{KCl}$. One possible reason could be that in these studies, $\mathrm{KCl}$ was applied in a hyperosmotic manner and it has been shown that a component of this contraction is independent of extracellular $\mathrm{Ca}^{2+}[39]$ and is somewhat insensitive to $\mathrm{Ca}^{2+}$ channel blockers. This may also explain why neither hibiscus nor garcinia acid caused complete relaxation of the aorta when it was pre-contracted with $\mathrm{KCl}$. With regard to removal of the endothelium affecting the sensitivity of the aorta to hibiscus or garcinia acid, such an effect has also previously been observed with classical $\mathrm{Ca}^{2+}$ channel blockers [40] and this has been attributed to their ability to stimulate the endothelial cells to release nitric oxide $[41,42]$.

The contraction induced by $\mathrm{PE}$ involves both $\mathrm{Ca}^{2+}$ release from the sarcoplasmic reticulum (SR) and $\mathrm{Ca}^{2+}$ influx from the extracellular medium via receptor-operated (ROCCs), and VDCCs $[43,44]$. Given that neither hibiscus nor garcinia acid affected the phasic contraction 
produced by $\mathrm{PE}$ in the absence of extracellular $\mathrm{Ca}^{2+}$, it seems unlikely that they are affecting $\mathrm{Ca}^{2+}$ release from the SR. The fact that this initial transient contraction was unaffected by either hibiscus or garcinia acid also indicates that these agents are unlikely to be affecting the biochemical sequence of events that links the increase in $\mathrm{Ca}^{2+}$ concentration to contraction [45]. Nevertheless, this is in contrast to what has been reported previously for the crude aqueous extract of $H$. sabdariffa, where there was $\sim 30 \%$ reduction in the magnitude of the phasic contraction to noradrenaline [27]. Following the phasic response to PE, the re-addition of $\mathrm{Ca}^{2+}$ produced a sustained contraction that is due to the influx of extracellular $\mathrm{Ca}^{2+}$. Both hibiscus and garcinia were found to produce relaxation of this tonic component, thereby further supporting their inhibitory effect upon $\mathrm{Ca}^{2+}$ influx.

While the above findings suggest that hibiscus and garcinia acid are producing vasorelaxation through inhibition of VDCCs, it is also possible that activation of $\mathrm{K}^{+}$channels may be involved [46]. However, the finding that the non-selective $\mathrm{K}^{+}$channel blocker TEA, did not prevent the relaxation to either hibiscus or garcinia acid would argue against them having a major role. There was a slight, but significant rightward shift in the concentration-response curve to both hibiscus and garcinia acid in the presence of TEA, which reflects a decrease in the sensitivity of the aorta to the relaxant effects of both acids. This could be attributed to the noted additional contraction produced by TEA itself. The decrease in potassium conductance caused by TEA, will result in depolarisation of the smooth muscle cell membrane, thereby producing a contraction [47]. Typically when $\mathrm{K}^{+}$channels are responsible for a relaxant effect, TEA has been found to reduce the magnitude of the relaxation by $>60 \%[48,49]$.

A variety of bioactive constituents have previously been identified in the calyces of $H$. sabdariffa, including phenolic acids, anthocyanins, and flavonoids [3]. However, very few 
studies have focussed on the pharmacological activities of the constituents identified. Hibiscus and garcinia acids are diastereomeric $\gamma$-lactones derived from $(2 \mathrm{~S}, 3 \mathrm{R})$ and $(2 \mathrm{~S}, 3 \mathrm{~S})$ 2-hydroxycitric acid, respectively [50,51]. Only certain species of plants are known to be capable of synthesising hydroxycitric acid [52]; thus, hibiscus and garcinia acids are substances which are not found extensively in all plants. Hydroxycitric acid with the absolute configuration $(2 \mathrm{~S}, 3 \mathrm{~S})$, is a major acid component in the fruit rinds of garcinia species, including G. cambogia, G. indica, G. Cowa, and G. atroviridis [53-56]. Whereas, hydroxycitric acid with the configuration $(2 \mathrm{~S}, 3 \mathrm{R})$ is the hibiscus-type enantiomer, which is found predominantly in the calyces of $H$. sabdariffa, $H$. cannabinus and $H$. rosa-sinensis [53, 57, 58]. At present, details of the of the biosynthetic pathway for hydroxycitric acid and how it is regulated remain unclear [58]. One hypothesis is that hydroxycitric acid is generated via a condensation reaction of oxaloacetate with glycolyl-CoA [58].

Both hibiscus and garcinia acids appear to have similar activity and potency with regard to their ability to cause vasorelaxation. This is somewhat unusual, since the majority of enantiomers often have unequal pharmacological properties. For example, S(-)-verapamil is more potent than the $\mathrm{R}(+)$-verapamil enantiomer in terms of its vasodilatory effect, whilst diltiazem is diastereomer with two pair of enantiomers, but only the $(2 \mathrm{~S}, 3 \mathrm{~S})$ form is pharmacologically active [59]. Although rarer, there are nevertheless enantiomers that do have equal pharmacological activities; for example the antiarrhythmic flecainide and the antidepressant fluoxetine $[59,60]$.

\section{Conclusion}

This is the first report of a vasorelaxant effect for hibiscus acid, which could potentially explain the previously described vascular effects of $H$. sabdariffa, including its 
antihypertensive properties $[17,18]$. This study has also shown a comparable vasorelaxant activity with the diastereomer, garcinia acid. Both acids appear to produce their vasorelaxant activity via blockade of the VDCCs in vascular smooth muscle cells, thereby inhibiting the influx of extracellular $\mathrm{Ca}^{2+}$. Furthermore, this study provides support for the traditional use of the extracts or teas of $H$. sabdariffa as an antihypertensive natural product.

Acknowledgments: We thank the University of Misan, and the Ministry of Higher Education, Iraq, for funding AZ.

Conflict of interest: None of the co-authors have any conflicts of interest, including financial interests and relationships and affiliations relevant to the subject matter or materials discussed in this manuscript.

\section{References}

[1] B.H. Ali, N. Al Wabel, G. Blunden, Phytochemical, pharmacological and toxicological aspects of Hibiscus sabdariffa L.: a review, Phytotherapy research : PTR 19(5) (2005) 36975.

[2] A.L. Hopkins, M.G. Lamm, J.L. Funk, C. Ritenbaugh, Hibiscus sabdariffa L. in the treatment of hypertension and hyperlipidemia: a comprehensive review of animal and human studies, Fitoterapia 85 (2013) 84-94.

[3] I. Da-Costa-Rocha, B. Bonnlaender, H. Sievers, I. Pischel, M. Heinrich, Hibiscus sabdariffa L. - A phytochemical and pharmacological review, Food chemistry 165 (2014) 424-443.

[4] M. Haji Faraji, A. Haji Tarkhani, The effect of sour tea (Hibiscus sabdariffa) on essential hypertension, J Ethnopharmacol 65(3) (1999) 231-6.

[5] A. Herrera-Arellano, S. Flores-Romero, M.A. Chavez-Soto, J. Tortoriello, Effectiveness and tolerability of a standardized extract from Hibiscus sabdariffa in patients with mild to moderate hypertension: a controlled and randomized clinical trial, Phytomedicine : international journal of phytotherapy and phytopharmacology 11(5) (2004) 375-82.

[6] A. Herrera-Arellano, J. Miranda-Sanchez, P. Avila-Castro, S. Herrera-Alvarez, J.E. Jimenez-Ferrer, A. Zamilpa, R. Roman-Ramos, H. Ponce-Monter, J. Tortoriello, Clinical effects produced by a standardized herbal medicinal product of Hibiscus sabdariffa on patients with hypertension. A randomized, double-blind, lisinopril-controlled clinical trial, Planta medica 73(1) (2007) 6-12. 
[7] H. Mozaffari-Khosravi, B.A. Jalali-Khanabadi, M. Afkhami-Ardekani, F. Fatehi, M. Noori-Shadkam, The effects of sour tea (Hibiscus sabdariffa) on hypertension in patients with type II diabetes, Journal of human hypertension 23(1) (2009) 48-54.

[8] D.L. McKay, C.Y. Chen, E. Saltzman, J.B. Blumberg, Hibiscus sabdariffa L. tea (tisane) lowers blood pressure in prehypertensive and mildly hypertensive adults, The Journal of nutrition 140(2) (2010) 298-303.

[9] H. Mozaffari-Khosravi, Z. Ahadi, K. Barzegar, The effect of green tea and sour tea on blood pressure of patients with type 2 diabetes: a randomized clinical trial, Journal of dietary supplements 10(2) (2013) 105-15.

[10] P.C. Onyenekwe, E.O. Ajani, D.A. Ameh, K.S. Gamaniel, Antihypertensive effect of roselle (Hibiscus sabdariffa) calyx infusion in spontaneously hypertensive rats and a comparison of its toxicity with that in Wistar rats, Cell Biochem Funct 17(3) (1999) 199-206.

[11] I.P. Odigie, R.R. Ettarh, S.A. Adigun, Chronic administration of aqueous extract of Hibiscus sabdariffa attenuates hypertension and reverses cardiac hypertrophy in $2 \mathrm{~K}-1 \mathrm{C}$ hypertensive rats, Journal of ethnopharmacology 86(2-3) (2003) 181-5.

[12] F.B. Mojiminiyi, M. Dikko, B.Y. Muhammad, P.D. Ojobor, O.P. Ajagbonna, R.U. Okolo, U.V. Igbokwe, U.E. Mojiminiyi, M.A. Fagbemi, S.O. Bello, T.J. Anga, Antihypertensive effect of an aqueous extract of the calyx of Hibiscus sabdariffa, Fitoterapia 78(4) (2007) 292-7.

[13] M.G. Abubakar, A.N. Ukwuani, U.U. Mande, Antihypertensive activity of Hibiscus Sabdariffa aqueous calyx extract in Albino rats, Sky Journal of Biochemistry Research 4(3) (2015) $016-020$.

[14] M.B. Ali, W.M. Salih, A.H. Mohamed, A.M. Homeida, Investigation of the antispasmodic potential of Hibiscus sabdariffa calyces, J Ethnopharmacol 31(2) (1991) 24957.

[15] P.C.M. Obiefuna, O.A. Owolabi, B.J. Adegunloye, I.P. Obiefuna, O.A. Sofola, The Petal Extract of Hibiscus sabdariffa Produces Relaxation of Isolated Rat Aorta, International Journal of Pharmacognosy 32(1) (1994) 69-74.

[16] B.J. Adegunloye, J.O. Omoniyi, O.A. Owolabi, O.P. Ajagbonna, O.A. Sofola, H.A. Coker, Mechanisms of the blood pressure lowering effect of the calyx extract of Hibiscus sabdariffa in rats, Afr J Med Med Sci 25(3) (1996) 235-8.

[17] M. Ajay, H.J. Chai, A.M. Mustafa, A.H. Gilani, M.R. Mustafa, Mechanisms of the antihypertensive effect of Hibiscus sabdariffa L. calyces, J Ethnopharmacol 109(3) (2007) 38893.

[18] M. Sarr, S. Ngom, M.O. Kane, A. Wele, D. Diop, B. Sarr, L. Gueye, R. Andriantsitohaina, A.S. Diallo, In vitro vasorelaxation mechanisms of bioactive compounds extracted from Hibiscus sabdariffa on rat thoracic aorta, Nutr Metab (Lond) 6 (2009) 45.

[19] A.M. Salah, J. Gathumbi, W. Vierling, Inhibition of intestinal motility by methanol extracts of Hibiscus sabdariffa L. (Malvaceae) in rats, Phytotherapy research : PTR 16(3) (2002) 283-5. 
[20] A.M. Fouda, M.H. Daba, G.M. Dahab, Inhibitory effects of aqueous extract of Hibiscus sabdariffa on contractility of the rat bladder and uterus, Canadian journal of physiology and pharmacology 85(10) (2007) 1020-31.

[21] A.M. Zheoat, A.I. Gray, J.O. Igoli, A.R. Kennedy, V.A. Ferro, Crystal structures of hibiscus acid and hibiscus acid dimethyl ester isolated from Hibiscus sabdariffa (Malvaceae), Acta crystallographica. Section E, Crystallographic communications 73(Pt 9) (2017) 13681371.

[22] W. Zheng, D. Rampe, D.J. Triggle, Pharmacological, radioligand binding, and electrophysiological characteristics of FPL 64176, a novel nondihydropyridine Ca2+ channel activator, in cardiac and vascular preparations, Molecular pharmacology 40(5) (1991) 73441.

[23] G. Thomas, M. Chung, C.J. Cohen, A dihydropyridine (Bay k 8644) that enhances calcium currents in guinea pig and calf myocardial cells. A new type of positive inotropic agent, Circulation research 56(1) (1985) 87-96.

[24] B. Roy, B. Sicotte, M. Brochu, J. St-Louis, Effects of nifedipine and Bay K 8644 on myotropic responses in aortic rings of pregnant rats, Eur J Pharmacol 280(1) (1995) 1-9.

[25] K. Nishimura, M. Ota, K. Ito, Existence of two components in the tonic contraction of rat aorta mediated by alpha 1-adrenoceptor activation, British journal of pharmacology 102(1) (1991) 215-21.

[26] A. Novakovic, L.G. Bukarica, V. Kanjuh, H. Heinle, Potassium channels-mediated vasorelaxation of rat aorta induced by resveratrol, Basic \& clinical pharmacology \& toxicology 99(5) (2006) 360-4.

[27] O.A. Owolabi, B.J. Adegunloye, O.P. Ajagbona, O.A. Sofola, P.C.M. Obiefuna, Mechanism of Relaxant Effect Mediated by an Aqueous Extract of Hibiscus sabdariffa Petals in Isolated Rat Aorta, International Journal of Pharmacognosy 33(3) (1995) 210-214.

[28] M. Micucci, M. Malaguti, T. Gallina Toschi, G. Di Lecce, R. Aldini, A. Angeletti, A. Chiarini, R. Budriesi, S. Hrelia, Cardiac and Vascular Synergic Protective Effect of Olea europea L. Leaves and Hibiscus sabdariffa L. Flower Extracts, Oxidative Medicine and Cellular Longevity 2015 (2015) 318125.

[29] T. Godfraind, C. Egleme, I. Al Osachie, Role of endothelium in the contractile response of rat aorta to alpha-adrenoceptor agonists, Clinical science (London, England : 1979) 68 Suppl 10 (1985) 65s-71s.

[30] C. van Breemen, O. Hwang, K.D. Meisheri, The mechanism of inhibitory action of diltiazem on vascular smooth muscle contractility, The Journal of pharmacology and experimental therapeutics 218(2) (1981) 459-63.

[31] T. Godfraind, Actions of nifedipine on calcium fluxes and contraction in isolated rat arteries, Journal of Pharmacology and Experimental Therapeutics 224(2) (1983) 443-450.

[32] H. Karaki, G.B. Weiss, Calcium channels in smooth muscle, Gastroenterology 87(4) (1984) 960-70. 
[33] T. Godfraind, Calcium entry blockade and excitation contraction coupling in the cardiovascular system (with an attempt of pharmacological classification), Acta pharmacologica et toxicologica 58 Suppl 2 (1986) 5-30.

[34] N. Morel, T. Godfraind, Characterization in rat aorta of the binding sites responsible for blockade of noradrenaline-evoked calcium entry by nisoldipine, British journal of pharmacology 102(2) (1991) 467-77.

[35] K. Okumura, K. Ichihara, M. Nagasaka, Effects of Aranidipine, a Novel Calcium Channel Blocker, on Mechanical Responses of the Isolated Rat Portal Vein: Comparison with Typical Calcium Channel Blockers and Potassium Channel Openers, Journal of Cardiovascular Pharmacology 29(2) (1997) 209-215.

[36] H. Yamamoto, O. Hwang, C. Van Breemen, Bay K8644 differentiates between potential and receptor operated Ca2+ channels, Eur J Pharmacol 102(3-4) (1984) 555-7.

[37] D. Rampe, R.C. Dage, Functional interactions between two Ca2+ channel activators, (S)-Bay K 8644 and FPL 64176, in smooth muscle, Molecular pharmacology 41(4) (1992) 599-602.

[38] M. Auguet, S. Delaflotte, P.-E. Chabrier, E. Pirotzky, F. Clostre, P. Braquet, Endothelin and $\mathrm{Ca}++$ agonist bay $\mathrm{K}$ 8644: Different vasoconstrictive properties, Biochemical and biophysical research communications 156(1) (1988) 186-192.

[39] H. Karaki, H.Y. Ahn, N. Urakawa, Hyperosmotic applications of $\mathrm{KCl}$ induce vascular smooth muscle contraction which is independent of external $\mathrm{Ca}$, Japanese journal of pharmacology 33(1) (1983) 246-8.

[40] G. Kojda, W. Klaus, G. Werner, U. Fricke, The influence of endothelium on the action of PGF2 alpha and some dihydropyridine-type calcium antagonists in porcine basilar arteries, Basic research in cardiology 86(3) (1991) 254-65.

[41] J. Günther, S. Dhein, R. Rösen, W. Klaus, U. Fricke, Nitric oxide (EDRF) enhances the vasorelaxing effect of nitrendipine in various isolated arteries, Basic research in cardiology 87(5) (1992) 452-460.

[42] V.V. Brovkovych, L. Kalinowski, R. Muller-Peddinghaus, T. Malinski, Synergistic Antihypertensive Effects of Nifedipine on Endothelium : Concurrent Release of NO and Scavenging of Superoxide, Hypertension (Dallas, Tex. : 1979) 37(1) (2001) 34-39.

[43] T.B. Bolton, Mechanisms of action of transmitters and other substances on smooth muscle, Physiological reviews 59(3) (1979) 606-718.

[44] C.H. Lee, D. Poburko, P. Sahota, J. Sandhu, D.O. Ruehlmann, C. van Breemen, The mechanism of phenylephrine-mediated $[\mathrm{Ca}(2+)](\mathrm{i})$ oscillations underlying tonic contraction in the rabbit inferior vena cava, The Journal of physiology 534(Pt 3) (2001) 641-50.

[45] W.C. Miller-Hance, J.R. Miller, J.N. Wells, J.T. Stull, K.E. Kamm, Biochemical events associated with activation of smooth muscle contraction, The Journal of biological chemistry 263(28) (1988) 13979-82. 
[46] M.T. Nelson, J.M. Quayle, Physiological roles and properties of potassium channels in arterial smooth muscle, The American journal of physiology 268(4 Pt 1) (1995) C799-822.

[47] M. Nishio, S. Kigoshi, I. Muramatsu, Mechanisms of tetraethylammonium-induced contraction in the canine coronary artery, Pharmacology 33(5) (1986) 256-65.

[48] K.D. Meisheri, L.A. Dubray, J.J. Oleynek, A sensitive in vitro functional assay to detect $\mathrm{K}(+)$-channel-dependent vasodilators, Journal of pharmacological methods 24(4) (1990) 25161.

[49] K.D. Meisheri, M.A. Swirtz, S.S. Purohit, L.A. Cipkus-Dubray, S.A. Khan, J.J. Oleynek, Characterization of $\mathrm{K}+$ channel-dependent as well as -independent components of pinacidilinduced vasodilation, Journal of Pharmacology and Experimental Therapeutics 256(2) (1991) 492-499.

[50] P.M. Boll, E. Sorensen, E. Balieu, Naturally Occurring Lactones and Lactams. III. The absolute configuration of the hydroxycitric acid lactones; hibiscus acid and garcinia acid., Acta Chem. Scand. 23 (1969) 286-293.

[51] I. Ibnusaud, P.T. Thomas, R.N. Rani, P.V. Sasi, T. Beena, A. Hisham, Chiral $\gamma-$ butyrolactones related to optically active 2-hydroxycitric acids, Tetrahedron 58(24) (2002) 4887-4892.

[52] H. Hida, T. Yamada, Y. Yamada, Production of hydroxycitric acid by microorganisms, Bioscience, biotechnology, and biochemistry 69(8) (2005) 1555-61.

[53] Y.S. Lewis, S. Neelakantan, (-)-Hydroxycitric acid-the principal acid in the fruits of Garcinia cambogia desr, Phytochemistry 4(4) (1965) 619-625.

[54] J.M. Lowenstein, H. Brunengraber, [36] Hydroxycitrate, Methods in Enzymology, Academic Press 1981, pp. 486-497.

[55] B.S. Jena, G.K. Jayaprakasha, K.K. Sakariah, Organic Acids from Leaves, Fruits, and Rinds of Garcinia cowa, Journal of agricultural and food chemistry 50(12) (2002) 3431-3434.

[56] B.S. Jena, G.K. Jayaprakasha, R.P. Singh, K.K. Sakariah, Chemistry and biochemistry of (-)-hydroxycitric acid from Garcinia, Journal of agricultural and food chemistry 50(1) (2002) $10-22$.

[57] H. Hida, T. Yamada, Y. Yamada, Absolute configuration of hydroxycitric acid produced by microorganisms, Bioscience, biotechnology, and biochemistry 70(8) (2006) 1972-4.

[58] T. Yamada, H. Hida, Y. Yamada, Chemistry, physiological properties, and microbial production of hydroxycitric acid, Applied microbiology and biotechnology 75(5) (2007) 977 82.

[59] L.A. Nguyen, H. He, C. Pham-Huy, Chiral Drugs: An Overview, International Journal of Biomedical Science : IJBS 2(2) (2006) 85-100.

[60] B. Grodner, D. Sitkiewicz, [Enantiomers: a new problem in pharmacotherapy of depression?], Psychiatr Pol 47(3) (2013) 511-518. 
